\title{
Maintaining Key Services While Retaining Core Values: NYC Transit's Environmental Justice Strategies
}

\author{
Ted Wang, Alex Lu, Alla Reddy \\ MTA New York City Transit
}

\begin{abstract}
In a recession, transit agencies aim to provide key services while retaining national core values. When making service changes, federal funding recipients are prohibited from discriminating on the basis of race, color, or national origin and must not place undue burden on Environmental Justice (EJ) populations. To ensure compliance, New York City Transit developed analytical methodologies to identify impacts for the 50 proposed service rationalization initiatives, allowing for proactive mitigation. For 38 routes with span changes, load factor analysis across demographic and income categories (during periods of service elimination) demonstrated that impacts were equitably shared. For route changes, impacts were measured using shortest-path trip time and cost analysis using Census Transportation Planning Package Journeyto-Work data. The " $\mathrm{M}$ " and " $\mathrm{V}$ " Train modifications and the Co-op City bus restructuring illustrate package analysis of complex service changes, capturing mitigating effects of adjacent route restructurings. These service changes reduced costs while ensuring that Title VI/EJ communities were not disproportionately affected. After extensive EJ work and community outreach, the proposed changes were implemented in June 2010.
\end{abstract}




\section{Introduction}

Finding millions of dollars worth of savings in a public transit authority requires shared sacrifice among stakeholders. In 2010, the financial outlook for New York State was deteriorating. Taxes and levies that subsidize New York City Transit (NYCT) fell substantially short of projections. State government was cutting service, and transit needed to do the same to remain solvent. The goal was to keep key public services functioning while seeking budgetary savings. At the same time, the Federal Transit Administration (FTA) requires that funding recipients to comply with Title VI of the Civil Rights Act 1964, ensuring level and quality of service without regard to race, color, and nationality. Executive Order 12898 requires funding recipients to identify and address, as appropriate, disproportionately high and adverse human health and environmental effects, including social and economic effects of programs and activities on minority populations and low income populations (FTA Circular 4702.1A).

FTA provides guidance to transit operators on methods of compliance and allows room for flexibility. It is the operator's responsibility to develop its own Title $\mathrm{VI}$ and Environmental Justice (EJ) programs that comply with FTA and any local standards set by the agency. At the time of this writing, EJ issues are at the forefront of federal rulemaking, as FTA has released two proposed circulars (Circulars 4702.1B and 4703.1) for public comment. The proposals separate Title VI and EJ considerations and reiterate the requirements for service and fare change analysis. There are understandably widespread concerns within the transit practitioner's community.

This paper demonstrates methods used at NYCT and may serve as an example for other properties concerned with federal compliance when changing route and service span. The purpose of these changes is to seek long-term budgetary savings while minimizing the impact on the community and to safeguard federal funding by remaining in compliance with Title $\mathrm{VI}$ and Executive Order 12898. This was achieved through analytical methods detailed in this paper. The service changes discussed in this paper were implemented in June 2010.

\section{Strategic Elements of EJ/Title VI}

Title VI analysis is also a useful gauge on community relations. Being a good social steward brings positive attention to a business during a difficult time. Transportation infrastructure directly affects job access, property values, and livelihoods. Transit executives need to know the impacts of their decisions.

This information shows its worth when government officials and elected leaders invite transit executives to address concerns of their constituencies. The Oakland 
Airport Connector project raised concerns of three San Francisco community groups; they brought the issue to FTA (Thomas and McDaniel 2011), and in 2009, the operator was found to be in violation of Title VI and lost $\$ 50$ million in federal funding. Ensuring that actions taken by the transit operator are non-discriminatory requires proactive data analysis because outside groups are likely doing this already to influence the outcome. In 1996, Los Angeles County was required by a federal court decision to spend more than $\$ 1$ billion dollars on its bus system when external groups proved investments on light rail in wealthy neighborhoods were disproportionate compared to the bus network used by the majority of its customers (Garcia 2011). Proactive strategic analysis, therefore, allows operators to take the initiative in matters of decision making, public relations, funding, and control of finances.

Complying with Title VI and Environmental Justice requirements is the law, as well as the right thing to do. However, having first and foremost fulfilled the legal and moral imperatives, taking a proactive approach to Title VI provides the additional benefit of helping to maintain open channels of communication and a good working relationship with community stakeholders and regulators alike. Having a track record of going above and beyond builds an understanding that the operator is well-managed. Satisfying stakeholders consistently indicates that the operator is on the right track in service delivery.

\section{Literature Review}

A literature search for different strategies and analyses yielded a diversity of topics. Some of these reports are unique, such as the analysis done on American Indian tribal territories and transportation in relations to housing and demographics (Ward 2005). One paper described how a transit agency was found to be noncompliant with Title VI and strived to become compliant once again by reviewing the strategies of other operators (Bender et al. 2007). Another paper profiles a list of legal complaints pertaining to alleged Title VI violations (Thomas 2007). Others are more holistic, covering fare analysis, Americans with Disabilities Act (ADA) compliance, and Civil Rights. Recent papers use statistical significance testing to analyze Title VI data (Reddy et al. 2010). This is a logical development since it was already done in many areas: quality control, industrial engineering, and the social sciences, such as crime data mining. Many agencies at the New York Metropolitan Transportation Authority (MTA) have adopted this method of analysis. The contribution of NYCT's experience in 2010 provides focus on a particular case study where a large transit operator faced a financial situation and navigated itself to a fiscally-stronger position using detailed internal analysis as a guide. 


\section{Background}

In 2005, the MTA reduced fares by half for all riders during the holiday season to share with the public an unexpected budgetary surplus. Towards the end of 2007, the world economy entered a recession. Unemployment rose close to 10 percent (New York State Department of Labor 2011). Nationally, those numbers were higher for minority (Holt 2009) and young workers, especially for those with no college degree and even worse for those without a high school diploma (U.S. Department of Labor 2011). Gas prices remained historically high and had made their way past $\$ 4$ per gallon. Transit provided an alternative means of coping with the cost of auto operation.

Transit also had funding challenges, due to falling tax revenues and rising costs of resources such as fuel and labor. In October 2010, the MTA Board approved fare increases and service reductions for 2011. Title VI analysis found that monthly MetroCard holders tended to be more affluent than other fare media users (Hickey et al. 2010). The decision was to minimize impact on customers least able to pay. An $\$ 89$ monthly unlimited pass increased to $\$ 104$; weekly passes increased from $\$ 27$ to $\$ 29 ;$ single rides increased by 25 cents to $\$ 2.25$. Service changes were made to reflect ridership and return on investment. Before any route was discontinued, impact analyses were done to minimize, mitigate, or offset negative effects towards all transit users, especially minority and low-income riders.

Mass transit plays a vital role to those least able to afford private automobiles. Maintaining private auto ownership can cost close to $\$ 15,000$ annually in New York City (APTA 2011). "At or Below Poverty" is defined as a yearly income of $\$ 22,350$ for a family of four and $\$ 10,890$ for an individual (U.S. Dept. of Health and Human Services 2011). The poverty rate in New York City hovers around 20 percent (Roberts 2010). Despite fare increases, the average annual cost to use transit is a fraction of automobile ownership and can mean the difference between making ends meet or not.

\section{Selection of Analytical Techniques}

There were 50 service rationalization initiatives in 2010. According to guidelines adopted by the MTA in 1988, analysis was not needed if changes are less than 25 percent of the net route miles or less than 1 hour of the service span. A total of 14 initiatives out of the 50 did not surpass thresholds that would require a Title VI Analysis. The remaining initiatives needed a change analysis for route or span. Table 1 shows a selection of initiatives and affected segments and their corresponding analysis types (Span or Route). It was not applicable (N/A) if Title VI analysis was not required. 
Table 1. Type of Analysis for Sample List of Services to be Modified

\begin{tabular}{|c|c|c|c|c|c|}
\hline Route & Segment & $\begin{array}{c}\text { Route } \\
\text { or } \\
\text { Span }\end{array}$ & $\begin{array}{l}\text { \% Net } \\
\text { Change }\end{array}$ & $\begin{array}{l}\text { Above } \\
25 \% ?\end{array}$ & Notes \\
\hline $\begin{array}{l}\text { "Q" } \\
\text { "N" } \\
\text { "W" }\end{array}$ & $\begin{array}{l}\text { Queens Extension } \\
\text { Manhattan Local } \\
\text { All }\end{array}$ & $\begin{array}{l}\text { Route } \\
\text { N/A } \\
\text { Route }\end{array}$ & $\begin{array}{c}+32 \\
0 \\
-100\end{array}$ & $\begin{array}{l}\text { Yes } \\
\text { No } \\
\text { Yes }\end{array}$ & $\begin{array}{l}\text { Extend to Astoria } \\
\text { Replace "W" in North } \\
\text { Eliminated }\end{array}$ \\
\hline $\begin{array}{l}\text { "V" } \\
\text { "M" }\end{array}$ & $\begin{array}{l}\text { Queens Elimination } \\
\text { Queens Extension } \\
\text { Brooklyn Elimination }\end{array}$ & $\begin{array}{l}\text { Route } \\
\text { Route } \\
\text { N/A }\end{array}$ & $\begin{array}{l}-100 \\
+71 \\
-62\end{array}$ & $\begin{array}{l}\text { Yes } \\
\text { Yes } \\
\text { Yes }\end{array}$ & $\begin{array}{l}\text { Eliminated } \\
\text { Rerouted to replace "V" } \\
\text { Discontinued south of Delancey-Essex }\end{array}$ \\
\hline “G” & $\begin{array}{l}\text { Queens Elimination } \\
\text { Brooklyn Extension }\end{array}$ & $\begin{array}{l}\text { Route } \\
\text { N/A }\end{array}$ & $\begin{array}{l}-51 \\
+14\end{array}$ & $\begin{array}{l}\text { Yes } \\
\text { No }\end{array}$ & $\begin{array}{l}\text { Discontinued East of Court Sq. } \\
24 \mathrm{hr} \text { operation South of Court Sq. }\end{array}$ \\
\hline SIR & Stadium Service & N/A & -100 & Yes & Not a regularly scheduled service \\
\hline $\begin{array}{l}\text { BX25 } \\
B \times 26 \\
B \times 28 \\
B \times 30 \\
B \times 38\end{array}$ & $\begin{array}{l}\text { Co-op City } \\
\text { Co-op City } \\
\text { Co-op City } \\
\text { Co-op City } \\
\text { Co-op City }\end{array}$ & $\begin{array}{l}\text { Route } \\
\text { Route } \\
\text { Route } \\
\text { Route } \\
\text { Route }\end{array}$ & $\begin{array}{c}-100 \\
-33 \\
-29 \\
-3 \\
+100\end{array}$ & $\begin{array}{l}\text { Yes } \\
\text { Yes } \\
\text { Yes } \\
\text { No } \\
\text { Yes }\end{array}$ & $\begin{array}{l}\text { Elimination } \\
\text { Rerouted } \\
\text { Rerouted } \\
\text { New route }\end{array}$ \\
\hline $\begin{array}{l}\text { BX55 } \\
\text { BX15 }\end{array}$ & $\begin{array}{l}\text { Bronx } \\
\text { Bronx }\end{array}$ & $\begin{array}{l}\text { N/A } \\
\text { N/A }\end{array}$ & $\begin{array}{c}-23 \\
+8\end{array}$ & $\begin{array}{l}\text { No } \\
\text { No }\end{array}$ & \\
\hline $\mathrm{B} \times 20$ & Bronx & Span & -63 & Yes & \\
\hline $\begin{array}{l}\text { B1 } \\
\text { B8 } \\
\text { B64 } \\
\text { B70 }\end{array}$ & $\begin{array}{l}\text { Brooklyn } \\
\text { Brooklyn } \\
\text { Brooklyn } \\
\text { Brooklyn }\end{array}$ & $\begin{array}{l}\text { Route } \\
\text { Route } \\
\text { Route } \\
\text { Route }\end{array}$ & $\begin{array}{l}-21 \\
-15 \\
+41 \\
+31\end{array}$ & $\begin{array}{l}\text { No } \\
\text { No } \\
\text { Yes } \\
\text { Yes }\end{array}$ & \\
\hline B4 & Coney Island Av. East & N/A & -17 & No & Modified to operate via Avenue Z \\
\hline $\begin{array}{l}\text { B2 } \\
\text { B24 }\end{array}$ & $\begin{array}{l}\text { Brooklyn } \\
\text { Brooklyn }\end{array}$ & $\begin{array}{l}\text { Span } \\
\text { Span }\end{array}$ & $\begin{array}{l}-28 \\
-30\end{array}$ & $\begin{array}{l}\text { Yes } \\
\text { Yes }\end{array}$ & $\begin{array}{l}\text { Weekend discontinued } \\
\text { Weekend discontinued }\end{array}$ \\
\hline M22 & West of City Hall & $\mathrm{N} / \mathrm{A}$ & 0 & No & $\begin{array}{l}\text { Changes recinded due to public } \\
\text { hearing }\end{array}$ \\
\hline $\begin{array}{l}\text { M8 } \\
\text { M50 }\end{array}$ & $\begin{array}{l}\text { Manhattan } \\
\text { Manhattan }\end{array}$ & $\begin{array}{l}\text { Span } \\
\text { Span }\end{array}$ & $\begin{array}{l}-32 \\
-51\end{array}$ & $\begin{array}{l}\text { Yes } \\
\text { Yes }\end{array}$ & $\begin{array}{l}\text { Weekend discontinued } \\
\text { Weekend discontinued }\end{array}$ \\
\hline $\mathrm{S} 40 / 90$ & Staten Island & N/A & -5 & No & Discontinued to Howland Hook \\
\hline $\begin{array}{l}\text { S54 } \\
\text { S76 }\end{array}$ & $\begin{array}{l}\text { Staten Island } \\
\text { Staten Island }\end{array}$ & $\begin{array}{l}\text { Span } \\
\text { Span }\end{array}$ & $\begin{array}{c}-25 \\
0\end{array}$ & $\begin{array}{l}\text { Yes } \\
\text { No }\end{array}$ & \\
\hline $\begin{array}{l}\text { Q74 } \\
\text { Q75 } \\
\text { Q79 }\end{array}$ & $\begin{array}{l}\text { Queens } \\
\text { Queens } \\
\text { Queens }\end{array}$ & $\begin{array}{l}\text { Span } \\
\text { Span } \\
\text { Span }\end{array}$ & $\begin{array}{l}-100 \\
-100 \\
-100\end{array}$ & $\begin{array}{l}\text { Yes } \\
\text { Yes } \\
\text { Yes }\end{array}$ & $\begin{array}{l}\text { Eliminated } \\
\text { Eliminated } \\
\text { Eliminated }\end{array}$ \\
\hline X6 & Hylan Blvd & Route & -100 & Yes & Express Bus X6 eliminated \\
\hline
\end{tabular}




\section{Span Change Analysis}

It is efficient to reduce bus in-service hours when few people are riding. The following formula is used to determine number of seats occupied:

Load Factor $=($ Average Riders $/$ Trip) $/$ Bus Seats

Standard buses have 40 seats and articulated buses have 62 seats. A load factor of 20 percent on a standard bus means that, on average, only 8 seats are occupied at the peak load point during a span of time. A span change analysis is conducted when proposed cuts to service are considered "major," defined as exceeding more than 1 hour.

Three different span reduction actions were proposed in 2010: (a) span reduction by hour-up to two hours of service at the beginning or end of the day, (b) overnight service elimination (1:00-5:00 AM), and (c) off-peak and weekend service elimination-service may be reduced to weekdays or to peak hours only.

Equitability of span reduction is determined by comparing load factors during the period proposed for span reduction on impacted routes classified for Title VI as Minority or Non-Minority and for EJ as At or Below Poverty (Low Income), or Above Poverty (High Income). A route is defined as Minority if at least one-third of its total route mileage is in a Minority Census tract. The $1 / 3$ rule was first promulgated in Urban Mass Transportation Administration Circular C4702.1 (UMTA 1988) and was retained by NYCT despite the current FTA Circular C4702.1A that allowed each entity to develop local standards. This $1 / 3$ rule is also used to define "At or Below Poverty" routes. One can conclude from Table 2 that the routes selected for span reduction are low performing and sensible candidates for rationalization. 
Table 2. Bus Routes Analyzed for Service Span Reduction Load Factor Analysis

\begin{tabular}{|l|c|c|c|c|c|c|c|}
\hline \multicolumn{7}{|c|}{ (a) Span Reduction by Hour } \\
\hline Route & Day Type & Loads*/ Trip & Load Factor & Route & Day Type & Loads*/ Trip & Load Factor \\
\hline B64 & ALL & 4 & $10 \%$ & BX34 & ALL & 3 & $8 \%$ \\
\hline B67 & ALL & 3 & $7 \%$ & BX32 & WKD & 12 & $29 \%$ \\
\hline B2 & WKD & 4 & $10 \%$ & BX33 & WKD & 4 & $11 \%$ \\
\hline B9 & WKD & 4 & $10 \%$ & BX33 & SAT & 7 & $18 \%$ \\
\hline B16 & WKD & 6 & $15 \%$ & BX33 & SUN & 6 & $15 \%$ \\
\hline B9 & SAT & 4 & $9 \%$ & BX17 & SUN & 5 & $12 \%$ \\
\hline B9 & SUN & 3 & $8 \%$ & B7 & ALL & 6 & $14 \%$ \\
\hline B16 & SUN & 3 & $8 \%$ & B31 & ALL & 3 & $7 \%$ \\
\hline M8 & ALL & 1 & $3 \%$ & B45 & ALL & 4 & $10 \%$ \\
\hline M16 & ALL & 3 & $6 \%$ & B57 & ALL & 6 & $15 \%$ \\
\hline M50 & ALL & 2 & $6 \%$ & B65 & ALL & 5 & $13 \%$ \\
\hline M66 & ALL & 2 & $5 \%$ & B11 & WKD & 4 & $10 \%$ \\
\hline M11 & WKD & 7 & $18 \%$ & B13 & WKD & 4 & $9 \%$ \\
\hline M20 & WKD & 6 & $16 \%$ & B24 & WKD & 10 & $24 \%$ \\
\hline M21 & WKD & 8 & $20 \%$ & M1 & ALL & 2 & $6 \%$ \\
\hline M20 & SAT & 6 & $15 \%$ & M22 & ALL & 1 & $3 \%$ \\
\hline Q30 & ALL & 3 & $9 \%$ & M22 & SAT & 3 & $8 \%$ \\
\hline S54 & WKD & 4 & $11 \%$ & M22 & SUN & 2 & $6 \%$ \\
\hline S57 & WKD & 5 & $13 \%$ & M100 & SAT & 6 & $14 \%$ \\
\hline S66 & WKD & 12 & $29 \%$ & M116 & SAT & 7 & $16 \%$ \\
\hline S57 & SAT & 3 & $7 \%$ & Q48 & SUN & 3 & $7 \%$ \\
\hline S57 & SUN & 4 & $9 \%$ & & & & \\
\hline
\end{tabular}


Table 2 (cont'd.). Bus Routes Analyzed for Service Span Reduction Load Factor Analysis

\begin{tabular}{|c|c|c|c|c|c|c|c|}
\hline \multicolumn{8}{|c|}{ (b) Overnight Service Elimination } \\
\hline \multicolumn{4}{|c|}{ Above Poverty } & \multicolumn{4}{|c|}{ At or Below Poverty } \\
\hline Route & Day Type & Loads*/Trip & Load Factor & Route & Day Type & Loads*/Trip & Load Factor \\
\hline B2 & WKD & 4 & $10 \%$ & B9 & WKD & 4 & $10 \%$ \\
\hline M8 & ALL & 1 & $3 \%$ & B16 & WKD & 6 & $15 \%$ \\
\hline M50 & ALL & 2 & $6 \%$ & B9 & SAT & 4 & $9 \%$ \\
\hline M66 & ALL & 2 & $5 \%$ & B9 & SUN & 3 & $8 \%$ \\
\hline M20 & WKD & 6 & $16 \%$ & B16 & SUN & 3 & $8 \%$ \\
\hline M20 & SAT & 6 & $15 \%$ & M16 & ALL & 3 & $6 \%$ \\
\hline Q30 & ALL & 3 & $9 \%$ & M11 & WKD & 7 & $18 \%$ \\
\hline S54 & WKD & 4 & $11 \%$ & M21 & WKD & 8 & $20 \%$ \\
\hline S57 & WKD & 5 & $13 \%$ & BX34 & ALL & 3 & $8 \%$ \\
\hline S66 & WKD & 12 & $29 \%$ & $\mathrm{~B} \times 32$ & WKD & 12 & $29 \%$ \\
\hline S57 & SAT & 3 & $7 \%$ & $\mathrm{~B} \times 33$ & WKD & 4 & $11 \%$ \\
\hline S57 & SUN & 4 & $9 \%$ & $\mathrm{~B} \times 33$ & SAT & 7 & $18 \%$ \\
\hline B31 & ALL & 3 & $7 \%$ & BX33 & SUN & 6 & $15 \%$ \\
\hline M1 & ALL & 2 & $6 \%$ & BX17 & SUN & 5 & $12 \%$ \\
\hline Q48 & SUN & 3 & $7 \%$ & B7 & ALL & 6 & $14 \%$ \\
\hline & & & & B45 & ALL & 4 & $10 \%$ \\
\hline & & & & B57 & ALL & 6 & $15 \%$ \\
\hline & & & & B65 & ALL & 5 & $13 \%$ \\
\hline & & & & B11 & WKD & 4 & $10 \%$ \\
\hline & & & & B13 & WKD & 4 & $9 \%$ \\
\hline & & & & B24 & WKD & 10 & $24 \%$ \\
\hline & & & & M22 & ALL & 1 & $3 \%$ \\
\hline & & & & M22 & SAT & 3 & $8 \%$ \\
\hline & & & & M22 & SUN & 2 & $6 \%$ \\
\hline & & & & M100 & SAT & 6 & $14 \%$ \\
\hline & & & & M116 & SAT & 7 & $16 \%$ \\
\hline
\end{tabular}




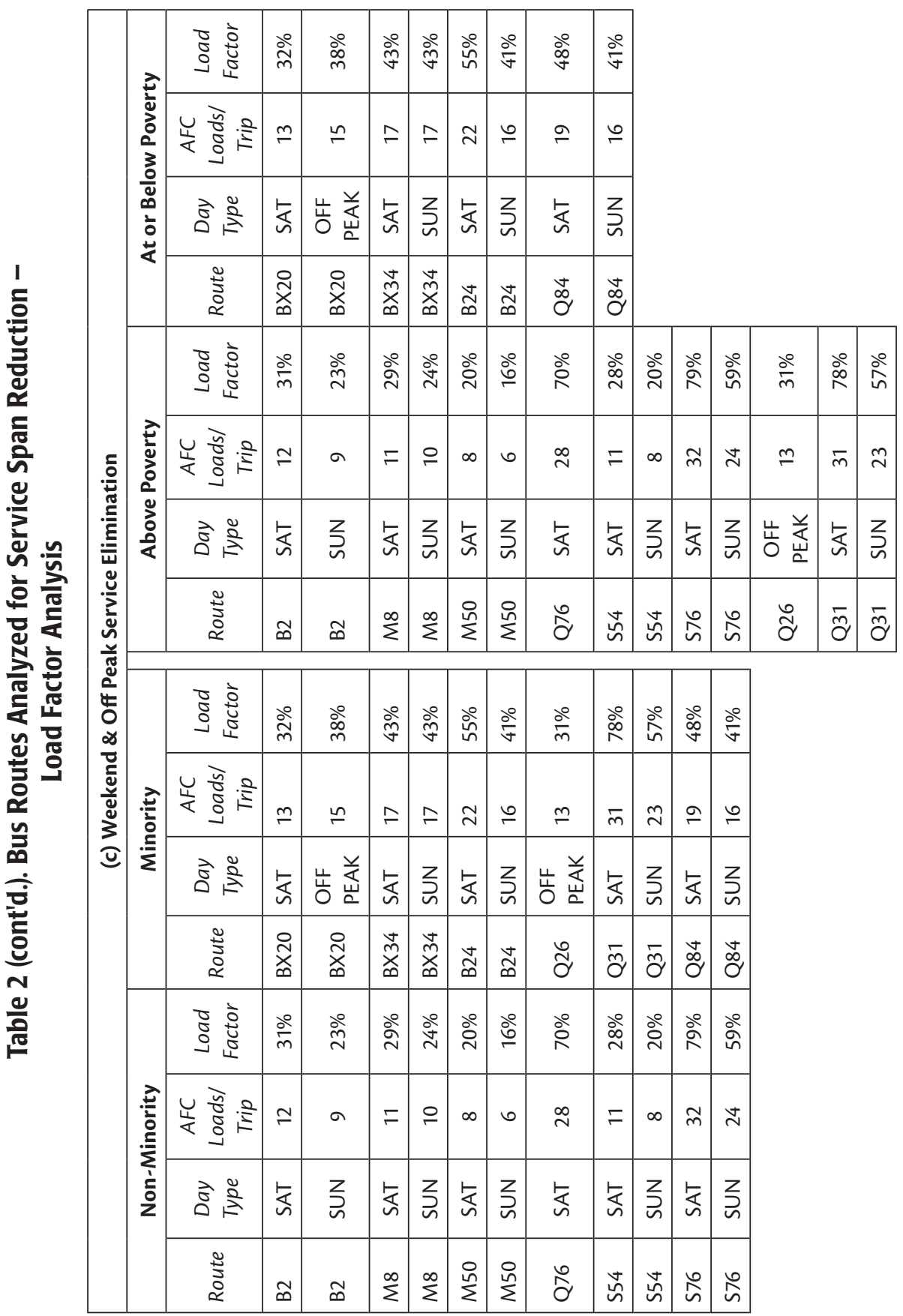


The average load factors shown Table 3 are less than 50 percent any day of the week for any socio-economic category. That means at least half of the bus seats are empty on weekends, overnight, and the first few hours of service at the beginning of the day and the last few hours at the end. When comparing Minority and Non-Minority on a weekday, the difference in average load factors is 1 percent. The difference between High and Low Income is 2 percent. The t-test shows "No disparity" among these groups. Statistically speaking, the differences between groups are not significant.

Table 3. Comparing Load Factors between Community Groups and Determining Disparity Using $\boldsymbol{t}$-Tests (Dataset in Table 2)

\begin{tabular}{|c|c|c|c|c|c|}
\hline & & \multicolumn{2}{|c|}{ Title VI } & \multicolumn{2}{|c|}{ Environmental Justice } \\
\hline & & Minority & $\begin{array}{c}\text { Non- } \\
\text { Minority }\end{array}$ & $\begin{array}{c}\text { At or Below } \\
\text { Poverty }\end{array}$ & $\begin{array}{l}\text { Above } \\
\text { Poverty }\end{array}$ \\
\hline \multirow{4}{*}{$\begin{array}{l}\text { Weekday } \\
\text { Analysis }\end{array}$} & Average load factor & $12 \%$ & $11 \%$ & $12 \%$ & $10 \%$ \\
\hline & Variance & 0.0038 & 0.0036 & 0.0034 & 0.0039 \\
\hline & $t$-test & \multicolumn{2}{|c|}{$-2.02<-0.60<2.02$} & \multicolumn{2}{|c|}{$-2.04<-1.32<2.04$} \\
\hline & Comparison results & \multicolumn{2}{|c|}{ No disparity } & \multicolumn{2}{|c|}{ No disparity } \\
\hline \multirow{4}{*}{$\begin{array}{l}\text { Weekend } \\
\text { Analysis }\end{array}$} & Average load factor & $46 \%$ & $36 \%$ & $43 \%$ & $40 \%$ \\
\hline & Variance & 0.018 & 0.049 & 0.0046 & 0.0529 \\
\hline & $t$-test & \multicolumn{2}{|c|}{$-2.12<-1.32<2.12$} & \multicolumn{2}{|c|}{$-2.11<-0.34<2.11$} \\
\hline & Comparison results & \multicolumn{2}{|c|}{ No disparity } & \multicolumn{2}{|c|}{ No disparity } \\
\hline
\end{tabular}

The load factor analysis acts on the systemwide level, with each route being a unit of analysis. This analysis is applicable when many routes are having their service spans reduced and essentially tests to see if span reductions are over-represented among certain routes to detect unintentional discrimination, if any. In contrast, route change analysis, discussed in the next section, is a route-by-route method that focuses on equity within the route, with Census tracts being the unit of analysis.

\section{Subway Route Change}

Working toward the goal of saving $\$ 4$ million per annum, planners at NYCT proposed eliminating the " $V$ " Train and replacing it with a rerouted and extended " $M$ " Train (Figure 1). The " $V$ " Train had relatively low ridership. The neighborhoods that lost and gained service had parity in demographics; thus, equity was preserved. Public hearings were held and comments were collected in March 2010. The route change offered a new Midtown direct service for riders originating from Middle Village, Ridgewood, and Fresh Pond in Queens and Bushwick and Williamsburg in 
Brooklyn. This modification was considered major because it changed at least 25 percent of the " $M$ " Train route length and, thus, required a Title VI analysis (NYCT 1985). The results from an Equity Analysis using a t-test showed that average travel times in affected Minority and Non-Minority areas showed no significant difference.

\begin{tabular}{|c|c|}
\hline \multicolumn{2}{|c|}{$\begin{array}{l}\text { NYC Transit } 2010 \text { Service Reduction Proposals } \\
\text { Profile of Elements }\end{array}$} \\
\hline \multicolumn{2}{|c|}{ 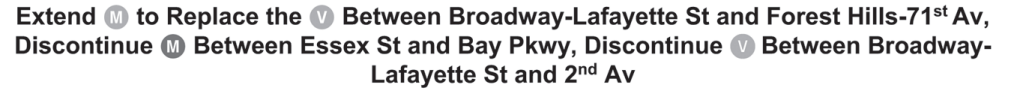 } \\
\hline Description of Action: & 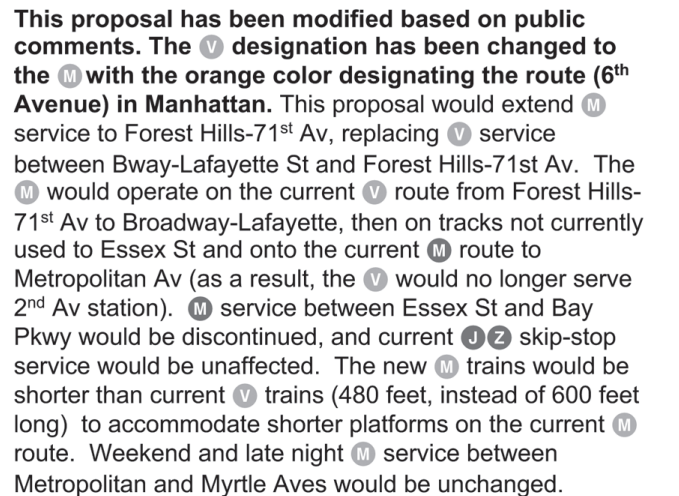 \\
\hline \multicolumn{2}{|c|}{$\begin{array}{c}\text { Neighborhoods/Trips Affected: Myrtle Corridor to Lower Manhattan, West End and } 4^{\text {th }} \text { Av } \\
\text { Corridor to Lower Manhattan, Queens Blvd. }\end{array}$} \\
\hline \multirow[t]{4}{*}{ Customer Impact: } & $\begin{array}{l}\text { South Brooklyn: } 10,000 \text { weekday riders from South } \\
\text { Brooklyn to Lower Manhattan }(1) \text { stations would require an } \\
\text { extra transfer to the R } 2345 \text { serving nearby stations } \\
\text { and/or a longer walk. } 16,000 \text { weekday riders traveling } \\
\text { between the West End line and } 4^{\text {th }} \text { Av local stations/ } \\
\text { Downtown Brooklyn stations would have an extra transfer. } \\
22,000 \text { weekday riders would wait longer for local trips } \\
\text { along the West End } / 4^{\text {th }} \text { Av line ( } 1.1 \text { extra minutes). }\end{array}$ \\
\hline & $\begin{array}{l}\text { North Brooklyn: } 17,000 \text { weekday riders from the Myrtle } \\
\text { corridor (including Hewes St, Lorimer St, and Flushing Av } \\
\text { stations) to Lower Manhattan would require a cross- } \\
\text { platform transfer. } 22,000 \text { weekday riders are projected to } \\
\text { take the new } \mathbb{M} \text {, benefiting from direct service to Midtown. }\end{array}$ \\
\hline & $\begin{array}{l}\text { Manhattan: } 19,000 \text { northbound riders at } 2^{\text {nd }} \text { Av station } \\
\text { would wait an average of } 0.75 \text { additional minutes. } 17,000 \\
\text { riders between Essex St and Broad St would wait an } \\
\text { average of } 0.6 \text { additional minutes. }\end{array}$ \\
\hline & $\begin{array}{l}\text { Queens: Queens Blvd and } 6^{\text {th }} \text { Av } \mathbb{\text { Miders would }} \\
\text { experience more riders per car due to shorter trains than } \\
\text { with the current }(\mathbb{Q} \text { (though within existing and proposed } \\
\text { loading guidelines). }\end{array}$ \\
\hline Initial Net Annual Savings: & $\$ 4.0$ million (No Change in Savings) \\
\hline
\end{tabular}

\section{Figure 1. "M" and "V" train service changes: (a) description from 2010 service reduction proposal, (b) schematic map}




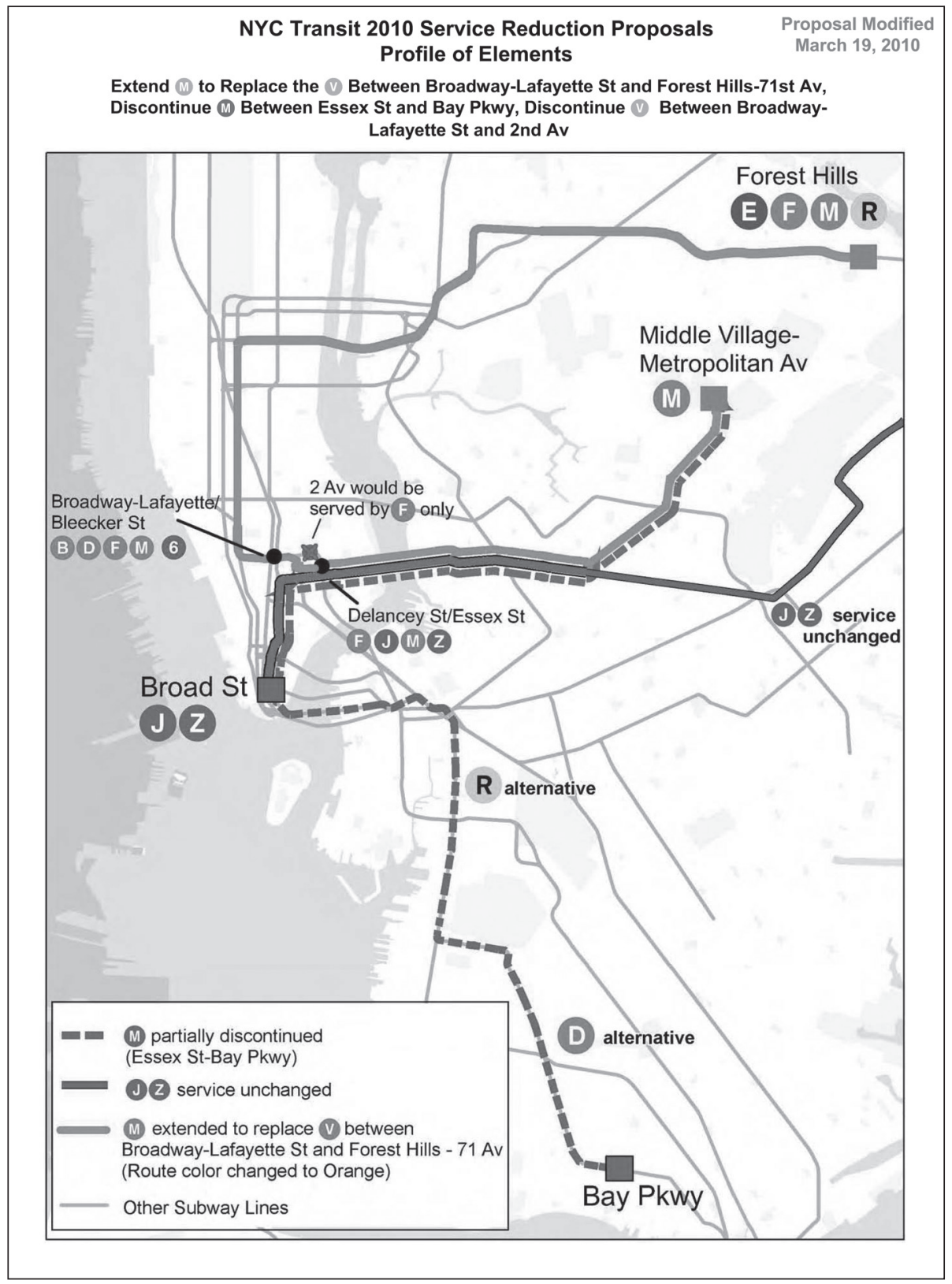

Figure 1 (cont'd.). " $M$ " and "V" train service changes: (a) description from 2010 service reduction proposal, (b) schematic map 


\section{Route Analysis Methods}

For routes that are being modified (eliminated or extended), or those that have greater than 25 percent of total revenue miles being changed, NYCT conducts a travel time and cost analysis. All Census tracts within $1 / 4$ mile of the route are reviewed. According to FTA Circular 4702.1A, a "Predominantly Minority Area" is a geographic area such as a neighborhood, Census tract, or traffic analysis zone where the proportion of minority persons residing in that area exceeds the average proportion of minority persons in the recipient's service area. The 2000 citywide average showed minorities to be 65.02 percent of the population of New York City. Thus, a Census tract in New York City is considered to be "Minority" if the minority population is equal to or greater than 65.02 percent; otherwise, it is defined as "Non-Minority." A Census tract is considered to be "At or Below Poverty" if the population is equal to or greater than the 2000 citywide average of 21.25 percent; otherwise, it is defined as "Above Poverty."

Thresholding is a necessary part of binary EJ analysis, where the population is divided into only two categories. Some observers feel it would be simpler or more appropriate to set the boundary at 50 percent, such that if more than half the people in a tract are minority, then the entire tract should be considered minority. However, this is problematic for New York City where minorities make up more than half of the population, resulting in most of the city being classified as minority and giving rise to analysis that would not be sensitive to actual disparities between heavily-minority areas versus somewhat-minority areas. Using the metro area average as the threshold is an appropriate way of ensuring that there is approximately same number of tracts in both categories, thereby maximizing the detection power of the statistical t-tests.

Similarly, defining areas of poverty at 50 percent will dramatically reduce the detection power of the analyses since most tracts will not meet the 50 percent threshold, and impact analysis may never be triggered. FTA provides guidelines on thresholds, and NYCT abides by the current standard practice (FTA C 4702.1A, 2007).

An Origin-Destination (O-D) table was created from the 2000 Census Journey-toWork Matrix, separately for Minority- and Non-Minority-originating Census tracts. The top five tracts in terms of passenger origination within $1 / 4$ mile of the route were selected. From these top five origin tracts, the top three destinations within NYCT's service area were selected, making a selection of 15 O-D pairs with heavy traffic on NYCT's services, on which travel time and cost analysis were conducted. 
1. The shortest path using the route being proposed for elimination is selected as the "before" travel time. The shortest path without the use of that route is the "after" travel time. The shortest path is recommended by a generic Web-based shortest-path journey planning tool.

2. If the shortest path is to walk between the origin and destination Census tracts, the walk time is entered and $\$ 0$ is entered for the fare.

3. In some cases, it is necessary to find the shortest path by forcing a transfer at an intermediate transfer point, as a trip planner is not always able to pick a path using the route in question. Paths are rejected for being unreasonable if they involve circuitous changes of direction (e.g., travel south on a bus in order to go back north on an express bus.)

4. If there is no way to use the subject route (e.g., the Census tract is at the northern end of the subject route, and the O-D pair requires the traveler to travel north; thus, every path involving the subject route results in a "go south to go north" condition), then the shortest path travel time is used for both the before and after conditions (i.e., elimination of route will have no impact for that O-D pair.)

The travel times and costs are found for each O-D pair before and after route modification. The average difference is calculated. $A t$-test is conducted to determine if the changes in travel times and cost are equitable.

\section{Application and Results}

This method was applied to the " $M$ " Train modification from Lower Manhattan to South Brooklyn. Prior to the major revamp of the subway map, the " $M$ " Train from Broad Street in Manhattan to Bay Parkway in Brooklyn was a dotted line, indicating a part-time extension. It ran only during rush hours Monday through Friday from 6:30-9:30 AM and 3:30-8:00 PM. There was no service available during midday, evenings, weekends, and late nights. Between Broad Street in Manhattan and 36th Street in Brooklyn, it shared the Montague Street tubes and 4th Avenue subway local tracks with "R" Trains. Then, it shared the West End Line tracks with " $D$ " Trains as far as Bay Parkway. The redundancy reduced the impact of its elimination. Table 4 illustrates the top five origins and top three destinations for the " $M$ " Train. The results are graphed in Table 5 to show the average difference in travel time and cost affecting four demographic categories before and after the " $M$ " Train was modified. 
The bar graph shows the differences before and after the " $M$ " Train modification (" $M$ " Elimination). In terms of average travel times for minorities, there is a fraction of a minute difference. The same is true for non-minorities. The comparison is between the average difference of minorities and non-minorities. The change was equitably small. The two-tailed test of hypothesis $(t$-test) confirms this conclusion of "No Significant Disparity." Due to the "One City, One Fare" policy, the average difference in total cost per trip between minority and non-minority riders are identical; therefore, there was no Title VI disparity. The average difference for Above Poverty and At or Below Poverty was also insignificant according to $t$-test results.

The new orange " $M$ " Train (" $M$ " Extension) runs from Broadway/Lafayette Street in Manhattan to Forest Hills in Queens. This extension completely replaces-and thus eliminates in name only-the " $V$ " Train. The neighborhoods the " $M$ " now travels through (all former " $\mathrm{V}$ " stops) include a largely non-minority and abovepoverty population in Manhattan. Once the " $M$ " Train crosses underneath the East River and enters Queens, the population becomes quite diverse in terms of race and income.

The methodology used to analyze the " $M$ " Extension and the " $V$ " Elimination is based on the route change analysis done on the " $M$ " modification in Lower Manhattan to South Brooklyn. There are geographic differences between the eliminated segment of the " $M$ " Train and the extended portion going into Queens. Brooklyn has higher transit density, providing more options for transfers. 


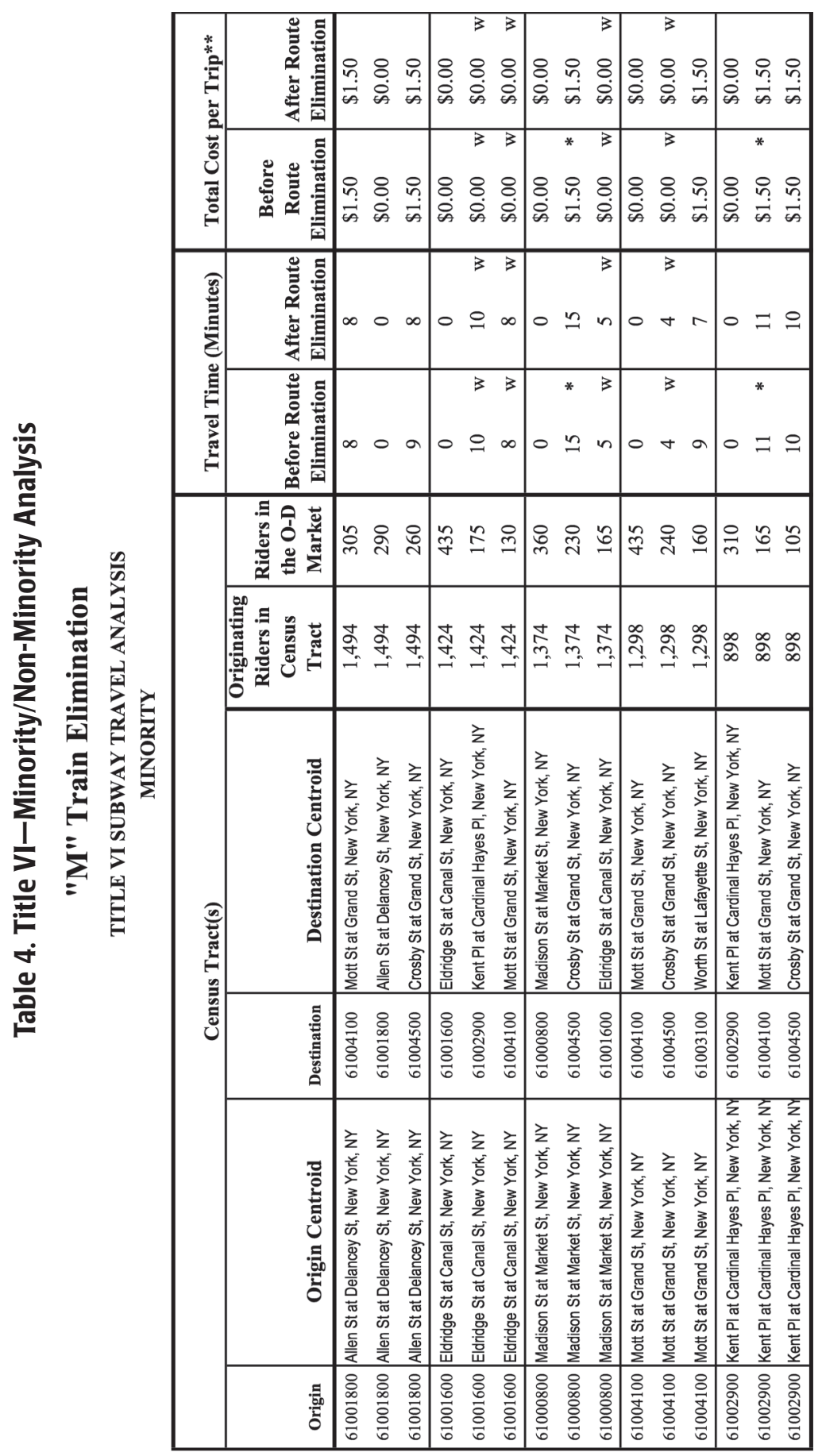




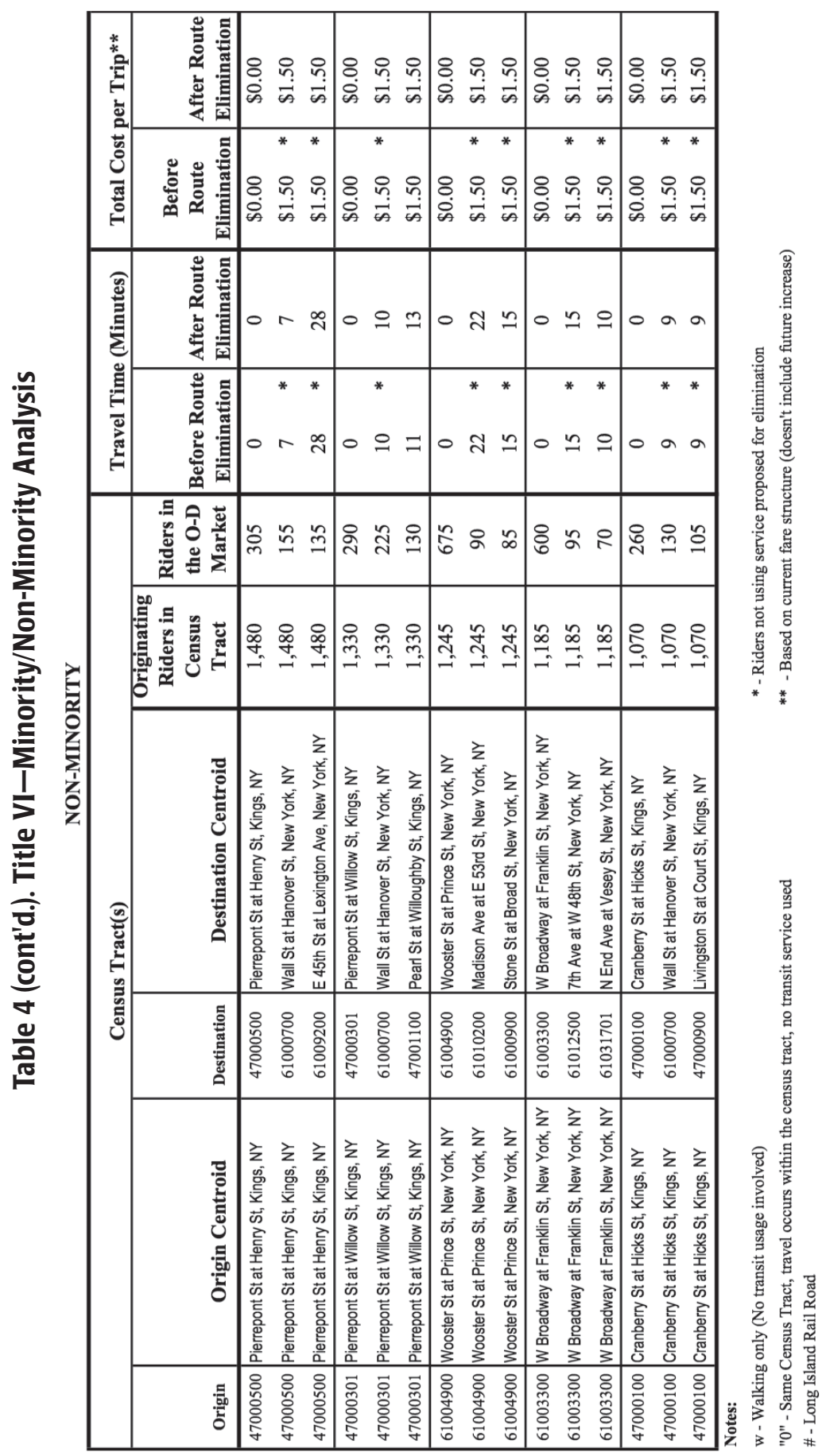




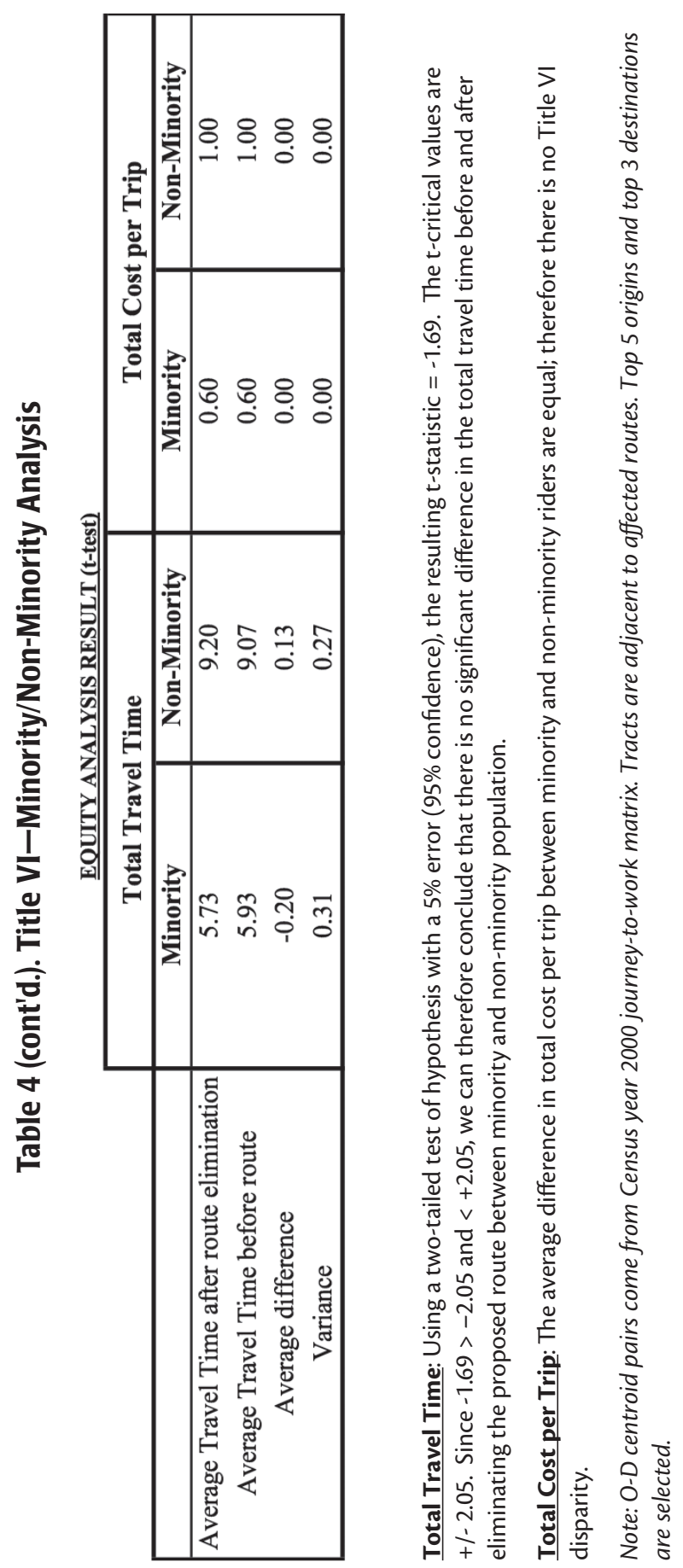


Table 5. Travel Time and Cost Analysis: "M" and "V" Subway Restructuring

\begin{tabular}{|c|c|c|c|c|c|c|}
\hline \multicolumn{7}{|c|}{ Travel Cost Analysis } \\
\hline Group & $\begin{array}{l}\text { Before } \\
\text { (Mins.) }\end{array}$ & $\begin{array}{c}\text { After } \\
\text { (Mins.) }\end{array}$ & $\begin{array}{l}\text { Avg. } \\
\text { Diff. }\end{array}$ & Var. & $t$-Test & Result \\
\hline "M" Elim Minority & 5.9 & 5.7 & -0.2 & 0.3 & $-2.05<-1.69<2.05$ & No disparity \\
\hline “M” Elim Non-Minority & 9.1 & 9.2 & 0.1 & 0.3 & & \\
\hline "V" Elim Minority & 15.4 & 15.1 & -0.3 & 0.4 & $-2.09<-1.54<2.09$ & No disparity \\
\hline "V" Elim Non-Minority & 4.7 & 4.7 & -0.1 & 0.1 & & \\
\hline "M" Ext Minority & 14.9 & 14.9 & 0.0 & 0.0 & Not required & No disparity \\
\hline "M" Ext Non-Minority & 4.7 & 4.7 & 0.0 & 0.0 & No change & \\
\hline "M" Elim Poverty & 5.7 & 5.5 & -0.2 & 0.3 & $-2.05<-1.69<2.05$ & No disparity \\
\hline “M” Elim Non-Poverty & 10.8 & 10.9 & 0.1 & 0.3 & & \\
\hline "V" Elim Poverty & 14.3 & 16.9 & 2.7 & 52.8 & $-2.14<1.46<2.14$ & No disparity \\
\hline "V" Elim Non-Poverty & 4.7 & 4.7 & -0.1 & 0.1 & & \\
\hline "M" Ext Poverty & 14.7 & 14.7 & 0.0 & 0.0 & Not required & No disparity \\
\hline "M" Ext Non-Poverty & 4.7 & 4.7 & 0.0 & 0.0 & No change & \\
\hline
\end{tabular}

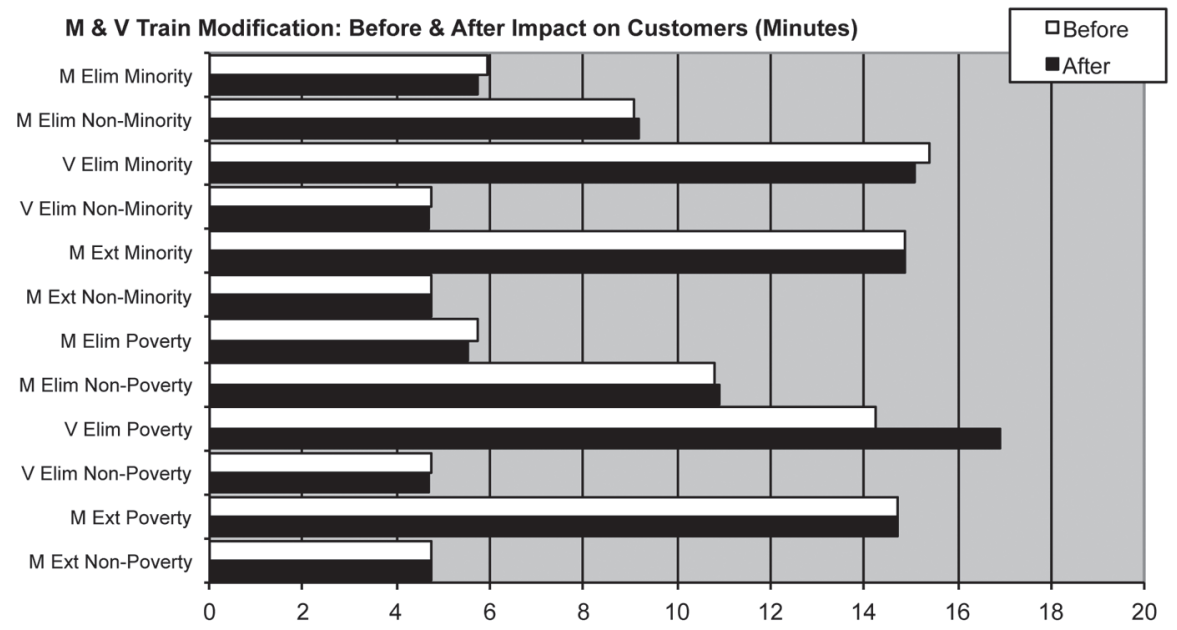


Table 5 (cont'd.). Travel Time and Cost Analysis: "M" and "V" Subway Restructuring

\begin{tabular}{|c|c|c|c|c|c|c|}
\hline \multicolumn{7}{|c|}{ Travel Cost Analysis } \\
\hline Group & Before & After & $\begin{array}{l}\text { Avg. } \\
\text { Diff. }\end{array}$ & Var. & $t$-Test & Result \\
\hline "M" Elim Minority & $\$ 0.60$ & $\$ 0.60$ & $0 €$ & $0 c$ & \multirow{2}{*}{$\begin{array}{l}\text { Not Required } \\
\text { No Change }\end{array}$} & \multirow[t]{2}{*}{ No disparity } \\
\hline "M" Elim Non-Minority & $\$ 1.00$ & $\$ 1.00$ & $0<$ & $0 c$ & & \\
\hline "V" Elim Minority & $\$ 1.23$ & $\$ 1.33$ & $10 \zeta$ & $15 c$ & \multirow[t]{2}{*}{$-2.14<1.00<2.14$} & \multirow[t]{2}{*}{ No disparity } \\
\hline "V" Elim Non-Minority & $\$ 0.90$ & $\$ 0.90$ & $0 c$ & $0 c$ & & \\
\hline "M" Ext Minority & $\$ 1.43$ & $\$ 1.43$ & $0 c$ & $0 c$ & \multirow{2}{*}{$\begin{array}{c}\text { Not required } \\
\text { No change }\end{array}$} & \multirow[t]{2}{*}{ No disparity } \\
\hline "M" Ext Non-Minority & $\$ 0.90$ & $\$ 0.90$ & $0 c$ & $0 c$ & & \\
\hline "M" Elim Poverty & $\$ 0.60$ & $\$ 0.60$ & $0 c$ & $0 c$ & \multirow{2}{*}{$\begin{array}{c}\text { Not required } \\
\text { No change }\end{array}$} & \multirow[t]{2}{*}{ No disparity } \\
\hline "M" Elim Non-Poverty & $\$ 1.00$ & $\$ 1.00$ & $0 c$ & $0 c$ & & \\
\hline "V" Elim Poverty & $\$ 0.90$ & $\$ 1.77$ & $87 c$ & $523 c$ & \multirow[t]{2}{*}{$-2.14<1.47<2.14$} & \multirow[t]{2}{*}{ No disparity } \\
\hline "V" Elim Non-Poverty & $\$ 0.90$ & $\$ 0.90$ & $0 c$ & $0 c$ & & \\
\hline "M" Ext Poverty & $\$ 2.20$ & $\$ 2.20$ & $0 c$ & $0 c$ & \multirow{2}{*}{$\begin{array}{l}\text { Not required } \\
\text { No change }\end{array}$} & \multirow[t]{2}{*}{ No disparity } \\
\hline "M" Ext Non-Poverty & $\$ 0.90$ & $\$ 0.90$ & $0 c$ & $0 c$ & & \\
\hline
\end{tabular}

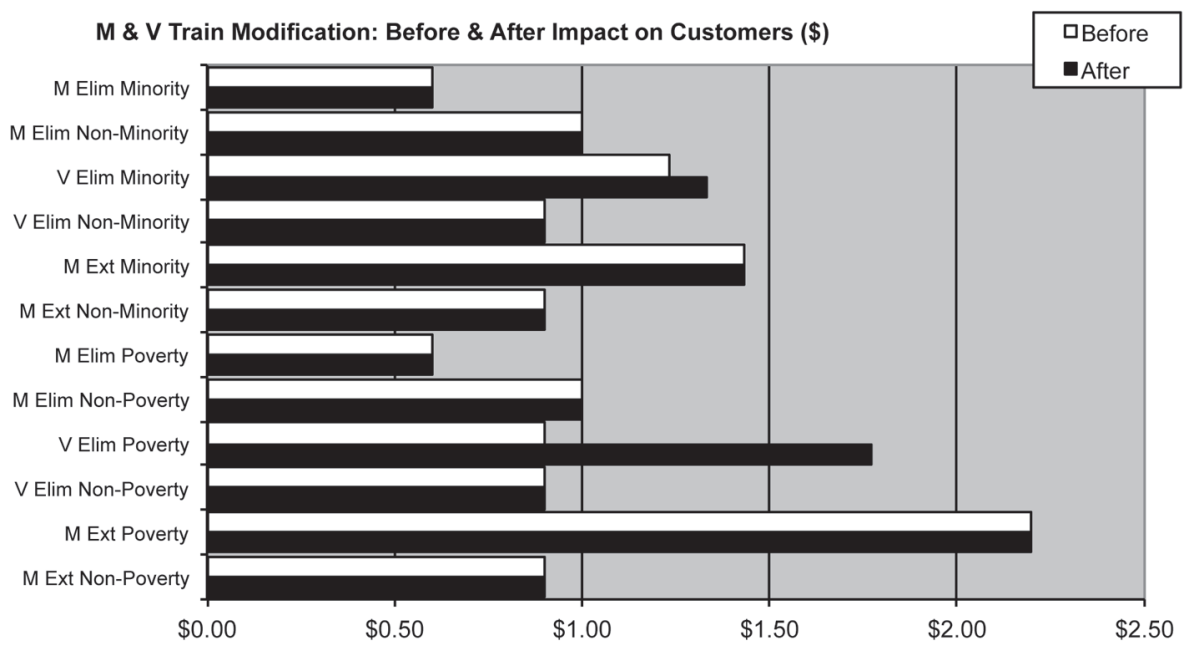

\section{Discussion}

The methodology takes into account people who walk distances up to a quarter mile, and there could be several stops in between. The distance between Allen Street at Delancey Street and Crosby Street at Grand Street is easily 4-5 minutes 
walking but has four separate subway stations within its vicinity. The variances in these O-D pair comparisons (Table 4) jump to 52.81 when trips between 31 Avenue at 34th Street in Queens and Stone Street at Broad Street in Manhattan are added. The distance between these two points is approximately 7 miles and requires, at minimum, a transfer between two train routes. The difference in travel time could range from 4 to 44 minutes.

The trip planner method has its limitations, and this could be seen when analysis was done on total cost per trip for the " $\mathrm{V}$ " Train elimination. The journey planner generates the top 3-5 shortest travel paths for each given O-D pair. On two occasions, it recommended use of the Long Island Rail Road (LIRR) - if no "V" Train were available-to travel between 35th Avenue at 71st Street, Queens and Midtown Manhattan, which is a distance of about five miles. The LIRR is a viable, if not more expensive, mode of transport for that trip. However, the trip planner (at time of analysis) could not take into account the fact that the new " $M$ " Train would replace the " $V$ " Train in its entirety and that, in reality, a subway option continued to be available. The journey planner data cannot be modified until these proposals are adopted and MTA releases appropriate timetable data. One can make an exception, but in this study, the method was strictly followed to ensure that NYCT has a consistent and defensible Title VI/EJ analytical method.

As a result of the " $V$ " Train elimination being analyzed separately from the " $M$ " Train re-route, the methodology makes the data appear that At or Below Poverty riders are paying almost twice as much as Above Poverty riders. In actuality, the fare did not change before or after the elimination of the " $\mathrm{V}$ " train. Based on new package analysis methodology submitted for FTA review, NYCT will analyze route changes such as the " $M$ " Train and the " $V$ " Train together in the future.

\section{Bus Service Change: Co-op City}

Co-op City is a middle-income housing development located on the northeast peninsula of the Bronx, privately built under New York's Mitchell-Lama limitedprofit housing program. It is not a separate municipal jurisdiction but is the name of a neighborhood that contains a high density of co-operatively-owned apartments situated on attractive parkland with easy access to parking and state parkways but not rail rapid public transit. Nearby amenities include a golf course, a beach, a shopping mall, and a municipal park. Per Census data, this neighborhood is Minority and Above Poverty. 
Consider the Title $\mathrm{VI}$ analysis of restructuring four bus lines in Co-op City. The cessation of an entire bus line (BX25) is projected to save $\$ 2.8$ million per annum. The other three buses (BX26, BX28, BX38) will be altered to absorb the ridership of $B \times 25: 1$ ) reroute the $B \times 26$ to match the eliminated $B \times 25$ path at all times (the BX25 designation would no longer be used); 2) split the BX28 into two branches, with one serving the northern section of Co-op City (which would be extended to Bay Plaza and numbered BX38) and one serving the southern section of Co-op City (which would be numbered BX28); and 3) BX38 will not enter Asch Loop. These buses serve as feeders to the " 2 " and " 5 " Trains going into Manhattan and Brooklyn; they also go to the Metro-North Williams Bridge commuter rail station.

$\mathrm{BX} 25, \mathrm{BX} 26$, and $\mathrm{BX} 28$ are considered Minority bus routes because at least $1 / 3$ of their total route mileage is in Minority Census tracts. These Census tracts are defined as Minority when 65.02 percent or more of their population are minority, per the 2000 New York City minority population threshold. Even though 34.98 percent or less are Non-Minorities, the entire Census tract is considered Minority. Thus, non-minorities do exist there even though the methodology treats these Census tracts as one or the other. Despite the route being predominately minority, the analysis compares the experience of minorities and non-minorities within the route by comparing Census tracts. The income levels are also worth mentioning because Co-op City is well known for being a community of the urban middle class popular among minorities and émigrés. The income requirements to live in Co-op City start at $\$ 23,160$ for up to two people, which is just above poverty.

The method of analysis to determine Title VI compliance in Co-op City is similar to the " $M$ " and " $V$ " Train modification discussed earlier. The difference is the additional variables of four routes being modified as opposed to just two for the " $M$ " and " $V$ " trains. The graphs on Table 6 show the changes in travel time and cost before and after modification. The average differences among the four socioeconomic categories are less than half a minute or zero. 
Table 6. Travel Time and Cost Analysis: Co-op City

\begin{tabular}{|l|cc|cc|c|c|}
\hline \multicolumn{7}{|c|}{ Travel Cost Analysis } \\
\hline \multicolumn{1}{|c|}{ Group } & $\begin{array}{c}\text { Before } \\
\text { (Mins.) }\end{array}$ & $\begin{array}{c}\text { After } \\
\text { (Mins.) }\end{array}$ & $\begin{array}{c}\text { Avg. } \\
\text { Diff. }\end{array}$ & Var. & t-Test & Result \\
\hline BX25 Minority & 25.5 & 25.5 & 0.0 & 0.0 & Not required & No disparity \\
BX25 Non-Minority & 24.1 & 24.1 & 0.0 & 0.0 & No change & \\
\hline BX26 Minority & 34.2 & 34.6 & 0.4 & 0.0 & No comparison & No disparity \\
BX26 Non-Minority & 0.0 & 0.0 & 0.0 & 0.0 & Data & \\
\hline BX28 Minority & 34.2 & 34.6 & 0.4 & 0.0 & No comparison & No disparity \\
BX28 Non-Minority & 0.0 & 0.0 & 0.0 & 0.0 & Data & \\
\hline BX38 Minority & 24.5 & 24.5 & 0.0 & 0.0 & Not required & No disparity \\
BX38 Non-Minority & 26.6 & 26.6 & 0.0 & 0.0 & No change & \\
\hline BX25 Poverty & 18.4 & 18.4 & 0.0 & 0.0 & Not required & No disparity \\
BX25 Non-Poverty & 30.6 & 30.6 & 0.0 & 0.0 & No change & \\
\hline BX26 Poverty & 0.0 & 0.0 & 0.0 & 0.0 & No comparison & No disparity \\
BX26 Non-Poverty & 31.9 & 32.3 & 0.4 & 0.0 & Data & \\
\hline BX28 Poverty & 0.0 & 0.0 & 0.4 & 0.0 & No comparison & No disparity \\
BX28 Non-Poverty & 31.9 & 32.3 & 0.4 & 0.0 & Data & \\
\hline BX38 Poverty & 16.9 & 16.9 & 0.0 & 0.0 & Not required & No disparity \\
BX38 Non-Poverty & 29.5 & 29.7 & 0.2 & 0.6 & No change & \\
\hline
\end{tabular}

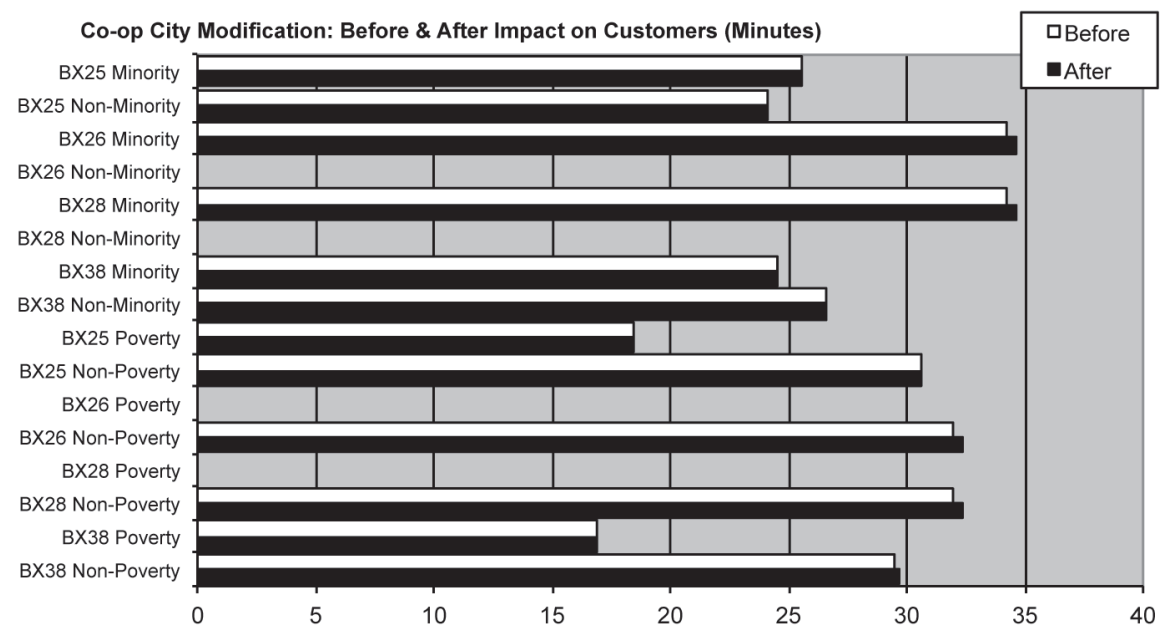


Table 6 (cont'd.). Travel Time and Cost Analysis: Co-op City

\begin{tabular}{|c|c|c|c|c|c|c|}
\hline \multicolumn{7}{|c|}{ Travel Cost Analysis } \\
\hline Group & Before & After & $\begin{array}{l}\text { Avg. } \\
\text { Diff. }\end{array}$ & Var. & $t$-Test & Result \\
\hline BX25 Minority & $\$ 1.22$ & $\$ 1.22$ & $0 c$ & $0 c$ & \multirow{2}{*}{$\begin{array}{l}\text { Not required } \\
\text { No change }\end{array}$} & \multirow[t]{2}{*}{ No disparity } \\
\hline BX25 Non-Minority & $\$ 1.32$ & $\$ 1.32$ & $0 c$ & $0 c$ & & \\
\hline BX26 Minority & $\$ 1.10$ & $\$ 1.10$ & $0 c$ & $0 \grave{c}$ & \multirow{2}{*}{$\begin{array}{c}\text { No comparison } \\
\text { Data }\end{array}$} & \multirow{2}{*}{ No disparity } \\
\hline BX26 Non-Minority & $\$ 0.00$ & $\$ 0.00$ & $0 c$ & $0 c$ & & \\
\hline BX28 Minority & $\$ 1.10$ & $\$ 1.10$ & $0 \zeta$ & $0 c$ & \multirow{2}{*}{$\begin{array}{c}\text { No comparison } \\
\text { Data }\end{array}$} & \multirow[t]{2}{*}{ No disparity } \\
\hline BX28 Non-Minority & $\$ 0.00$ & $\$ 0.00$ & $0<$ & $0<$ & & \\
\hline BX38 Minority & $\$ 1.51$ & $\$ 1.51$ & $0 \zeta$ & $0 c$ & \multirow{2}{*}{$\begin{array}{l}\text { Not required } \\
\text { No change }\end{array}$} & \multirow{2}{*}{ No disparity } \\
\hline BX38 Non-Minority & $\$ 1.20$ & $\$ 1.20$ & $0 c$ & $0 c$ & & \\
\hline BX25 Poverty & $\$ 1.53$ & $\$ 1.53$ & $0 c$ & $0 c$ & \multirow{2}{*}{$\begin{array}{l}\text { Not required } \\
\text { No change }\end{array}$} & \multirow[t]{2}{*}{ No disparity } \\
\hline BX25 Non-Poverty & $\$ 1.00$ & $\$ 1.00$ & $0 \subset$ & $0 c$ & & \\
\hline BX26 Poverty & $\$ 0.00$ & $\$ 0.00$ & $0 \zeta$ & $0 c$ & \multirow{2}{*}{$\begin{array}{c}\text { No comparison } \\
\text { Data }\end{array}$} & \multirow[t]{2}{*}{ No disparity } \\
\hline BX26 Non-Poverty & $\$ 1.10$ & $\$ 1.10$ & $0 c$ & $0 c$ & & \\
\hline BX28 Poverty & $\$ 0.00$ & $\$ 0.00$ & $0 \zeta$ & $0 \zeta$ & \multirow{2}{*}{$\begin{array}{c}\text { No comparison } \\
\text { Data }\end{array}$} & \multirow{2}{*}{ No disparity } \\
\hline BX28 Non-Poverty & $\$ 1.10$ & $\$ 1.10$ & $0 c$ & $0 c$ & & \\
\hline BX38 Poverty & $\$ 1.02$ & $\$ 1.02$ & $0 \zeta$ & $0 \zeta$ & \multirow{2}{*}{$\begin{array}{l}\text { Not required } \\
\text { No change }\end{array}$} & \multirow[t]{2}{*}{ No disparity } \\
\hline BX38 Non-Poverty & $\$ 1.19$ & $\$ 1.19$ & $0 c$ & $0 c$ & & \\
\hline
\end{tabular}

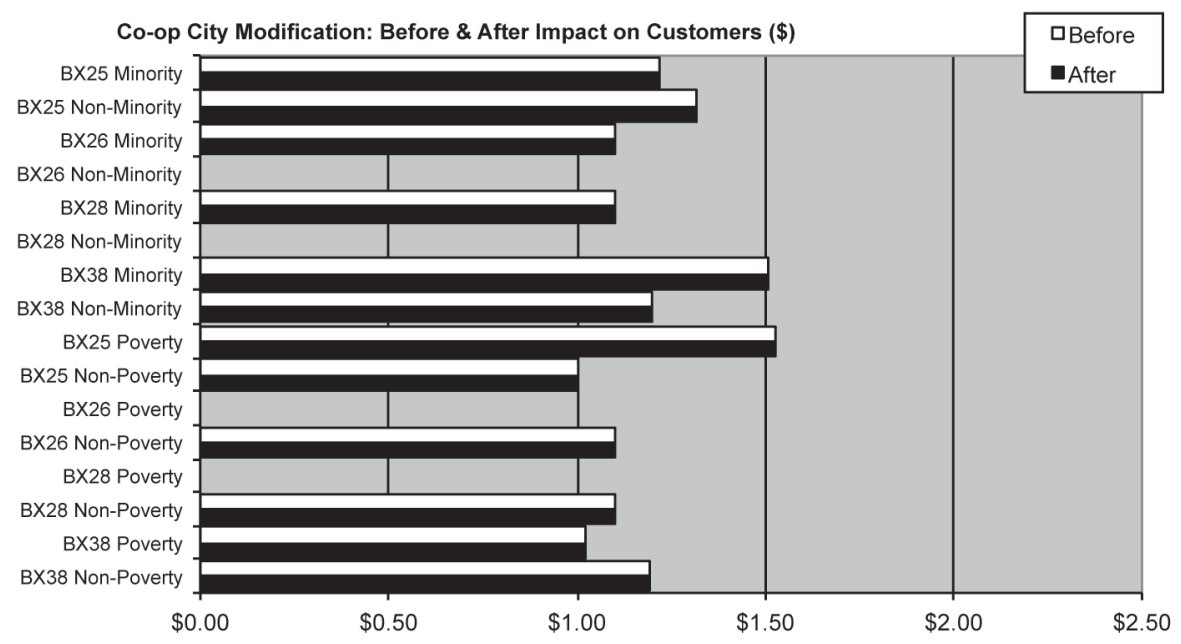


The top five origination method has a notable effect on the analysis. BX25 and BX26 travel along a similar path, but the top five origins for each route fall on different Census tracts. BX25 has data to compare between minorities and nonminorities. BX26 top five origins do not fall on any Non-Minority Census tracts, so there are no data to compare with Minority. BX26 top five origins do not fall on any At or Below Poverty Census tracts either, so there are no data to compare with Above Poverty tracts (Table 6).

\section{Public Reaction}

The residents of Co-op City formed a "Coalition to Stop the MTA Cuts" and presented a petition to the MTA and their elected representatives signed by thousands. Nine months of meetings among the stakeholders yielded "the relocating of a bus stop from under the I-95 overpass to a better lit location closer to Baychester Avenue. A request to add buses to the BX28 line serving the north section of the community during the overnight hours was accepted" (Stuttig 2011, 22).

Still, a local city council believed the concessions have not gone far enough. He called for the MTA to "return to the drawing board and make sure the residents of Co-op City are not stranded" (Stuttig 2011). Having learned that these cuts saves millions of dollar per year, he claimed that "Co-op City has received an unfair share of the cuts made system-wide and as such should be given some consideration for having some of the previous level of service restored." FTA auditors may be satisfied and are assured that the reductions have been necessary and fair. However, NYCT strives to be customer-oriented and has maintained communications and negotiations with community leaders and their constituents. There may be no legal requirement to do so, given the exhaustive Title VI and EJ analysis, but it is a matter of working in good faith with stakeholders. One local media outlet reported that "ridership data will be reviewed to determine if service adjustments need to be made. Bronx residents will be given opportunities to speak out at town hall meetings" (News 12 2011).

\section{Package Level Analysis}

Route level analysis is cumbersome and can be misleading because it does not capture the mitigating effects of restructuring other adjacent routes. A segment of the " $M$ " Train in this study was eliminated in one area of Census tracts that have route redundancy mitigating any impacts to riders there. The "V" Train was eliminated, but only in the sense that the designation was no longer used. The Queens Boulevard Line local track that the " $V$ " Train traveled was not physically removed. 
Riders still have access to train service with a different letter (" $M$ ") and, in some sense, can go further with fewer transfers than before. Yet, analysis of the " $V$ " Elimination absent the " $M$ " makes the result appear to impact one group more (albeit negligibly). Nevertheless, a route change has occurred and, thus, Title VI route level analysis must be done. The following formula summarizes when it is important to conduct an impact analysis as a package of changes.

Above $\mathrm{X} \%$ Net Route Miles Change $=$

(New Mileage + Eliminated Mileage) / $\Sigma$ (Original Route Mileage)

The X\% is for each operator to decide. At NYCT, if the X\% Net Route Miles Change is greater than 25 percent, then a package analysis should be conducted; no action is required if it is under 25 percent. Future NYCT Title VI analysis involving a combination of changes will use the method of package analysis in cases such as Co-op City. This method has been reviewed by FTA auditors and yields results that better represent the experiences of the riding public, not to mention making the analysis process easier.

Figure 2 is a hypothetical package analysis on a series of changes made to four routes. The focus of change is on Route 4 (or R4) because it is being eliminated. The original routes are R3, R4, R5, and R6. The gray horizontal line that makes a right-angle turn is $R 4$ and stretches from segments $E, F, G$, and $H$, ending at $D$. The adjacent $R 5$ is being extended to segment $E$, covering a portion of the R4 elimination. Segment $F$ would not be covered by any bus route, and riders will have to walk to bridge that distance. The adjacent R6 used to run in a straight line but, in order to cover a little more of the R4 elimination, now has to make a turn to run through segment $\mathrm{G}$ before heading south again to segment J. The distance of segment $\mathrm{H}$ also will not be covered by any bus route. The final segment to cover is $D$, which is taken over by extending R3. The modification of bus routes R5, R6, and R3 has now made bus route $R 4$ no longer necessary. The percent of net route change is the quotient produced by the above formula. If the percentage is above 25 percent, then a Title VI analysis will be necessary.

This method of rationalization keeps the network relatively intact, which means people can still get to where they need to go but with some impact in connectivity. A rider may be accustomed to riding $\mathrm{R} 5$ to the end and transferring to $\mathrm{R} 4$ to get towards $\mathrm{G}$. The transfer would be within the same block. Eliminating R4 means the rider has to walk distance $\mathrm{F}$ to catch R6 in order to complete the journey. 


\section{EXAMPLE: Package of Route Changes}

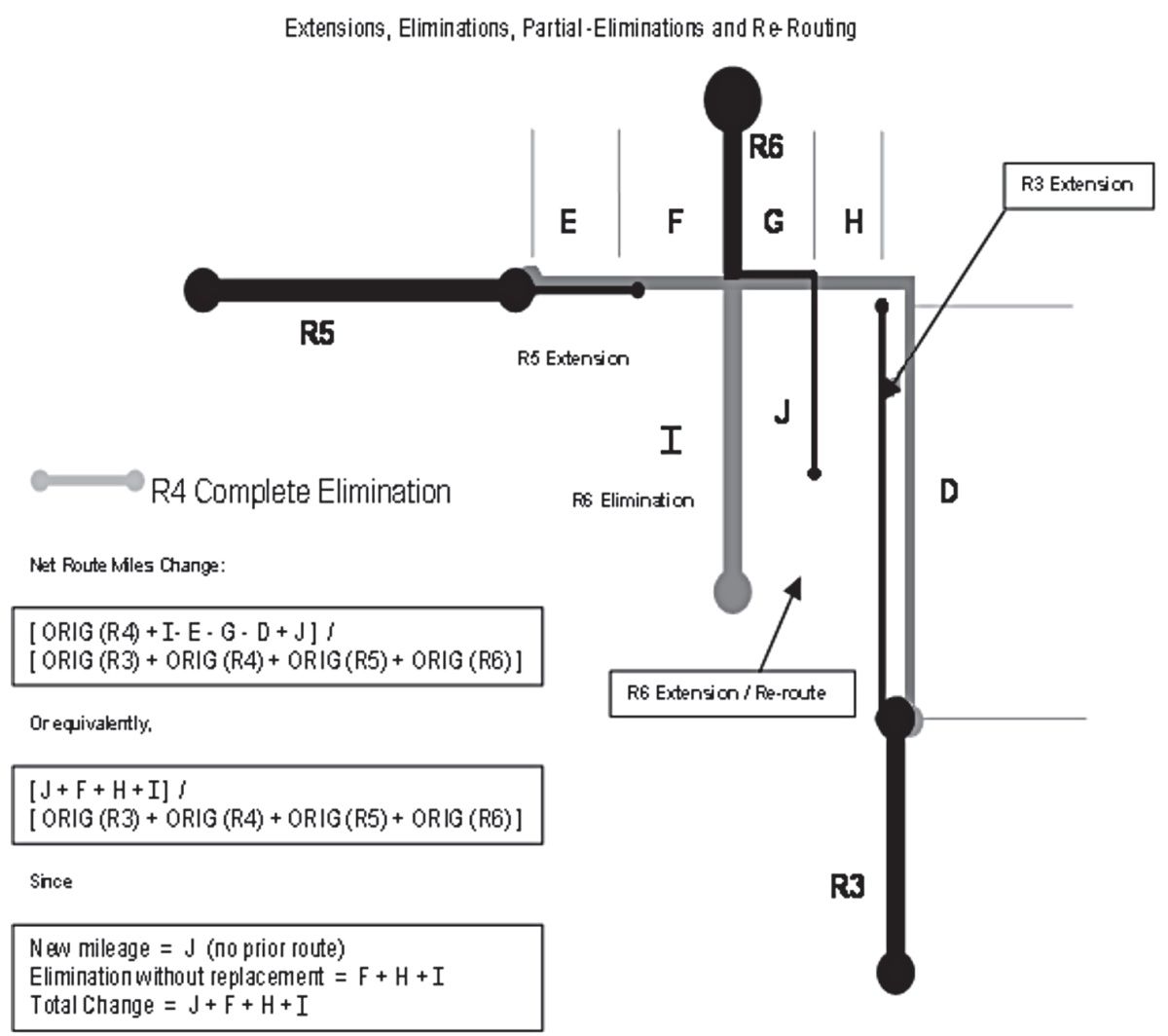

$\%$ Net Route Change $=$ Length $(\mathrm{J}+\mathrm{F}+\mathrm{H}+\mathrm{I}) /$ Length $(\mathrm{R} 3+\mathrm{R} 4+\mathrm{R} 5+\mathrm{R} 6)$

Figure 2. Net route change example in a package analysis

\section{Conclusion}

It is the dynamic communication with the community and the analysis of the customer base that ensures the provision of the best level of service with the resources available. This effort makes every dollar count. Proving to the public that the impact on travel time for minorities in Co-op City is minimal frames the grievance they may have about losing an entire bus line and counters anecdotal experiences of poor service. Even if the impact can be measured by minutes, it helps to show that, statistically speaking and as a measure on the whole, the change is equal for minori- 
ties and non-minorities on that route. The effort and methods invested could save the operator from having to reverse their decisions, which in itself is costly.

Analysis of these issues needs to evolve to meet the needs of the operator and the community. In the case of the " $M$ " and " $V$ " trains, it may have been appropriate to analyze them as one route because the two were designed to be complementary as parts of a package of service changes. Likewise, this method could also be used to conduct surface analysis in Co-op City. Although the restructuring of routes in rapid transit is infrequent, the future of these types of service changes will likely be analyzed as a combined "package" of changes to account for the complex and interlinked nature of such system modifications.

Despite the scientific methods, there is still a qualitative element that operators must heed. Title VI analyses are just tools employed in multi-lateral communication, ensuring that the operator, the riding public, and the government are all "on the same page" in terms of the effects of service changes on the community.

These methods for analyzing service changes are being developed at a time when the federal government is tightening the Title $\mathrm{VI}$ and $\mathrm{EJ}$ enforcement machinery through more thorough and detailed audits, promulgation of new rules, and requirements of transparency and accountability. FTA has affirmed its position through its proposed circulars, requiring all transit agencies to consider Title VI and $\mathrm{EJ}$ in service and fare changes that are becoming increasingly commonplace. Proper application of and further developing the methods discussed in this paper will allow the transit industry to move forward and maintain the balance between providing socially necessary services and upholding fiduciary responsibility. Retaining national core values require transit operators to go back to the basics: listening to the customers that it serves.

\section{Acknowledgments}

The authors would like to acknowledge the assistance of the following colleagues during this manuscript's development: Thomas Chennadu, Anthony Cramer, John Cucarese, Michael Kelly, Santosh Kumar, Brian Levine, and Svetlana Rudenko. Responsibility for errors or omissions remains with the authors. Opinions expressed are those of the authors and do not necessarily reflect official policy of Metropolitan Transportation Authority, MTA New York City Transit, or the Federal Transit Administration. 


\section{References}

American Public Transportation Association (APTA). 2011. Double digit rise in gas prices marks largest savings in nearly three years, giving public transit riders economic edge. http://www.apta.com/mediacenter/pressreleases/2011/ Pages/110414_TSR_april.aspx. Accessed June 1, 2011.

Bender, J., C. Bell, and B. Hill. 2007. Title Vl: implementing a transit equity program. DMJM Harris and Maryland Transit Administration.

Garcia, R. Transportation equity in Los Angeles: The MTA and beyond. Environmental Defense Fund. http://www.edf.org/article.cfm?contentID=1238. Accessed June 10, 2011.

Hickey, R. L., A. V. Reddy, and A. Lu. 2010. Using quantitative methods in equity and demographic analysis to inform transit fare restructuring decisions. Transportation Research Record, TRB Paper \#10-0280.

Holt, A. 2009. Women and people of color down for the count in jobless recovery. Huffington Post, October 13. http://www.huffingtonpost.com/arlene-holt/ women-and-people-of-color_b_318672.html Accessed June 1, 2011.

MTA New York City Transit. 1985. MTA guidelines-service change procedures. NYCT Operations Planning Department (Report OP - X85006), June 1.

New York State Department of Labor. 2011. Employed, unemployed, and rate of unemployed by place of residence for New York State and major labor areas. May. http://www.labor.ny.gov/stats/pressreleases/prtbur.txt Accessed June 1, 2011.

News 12. 2011. BX28 riders say cuts are hurting service. News 12 The Bronx, April 19.

Reddy, A. V., T. Chennadu, and A. Lu. 2010. Safeguarding minority civil rights and environmental justice in service delivery and reductions: Case study of New York City Transit Authority Title VI Program. Transportation Research Records 2163, TRB Paper \#10-1155.

Roberts, S. 2010. Calculating poverty in New York: More by city standard, and less by federal one. The New York Times, March 2.

Stuttig, B. 2011. Benedetto invites MTA chairman to tour Co-op City. Co-op City Times, March 26. 
Thomas, L. W., and J. B. McDaniel, J.B. 2011. Reductions in transit service or increases in fares: Civil rights, $A D A$, regulatory, and environmental justice implications. TCRP Legal Research Digest 35: 13-14.

Thomas, L. W. 2007. Civil rights implications of the allocation of funds between bus and rail. TCRP Legal Research Digest.

U.S. Department of Labor, Bureau of Labor Statistics. 2011. Employment status of the civilian population 25 years and over by educational attainment. http:// www.bls.gov/news.release/empsit.t04.htm Accessed June 1, 2011.

Urban Mass Transportation Administration (UMTA). 1988. Title VI Program guidelines for Urban Mass Transportation Administration recipients. Circular UMTA C4702.1 Section 1-3, May 26.

Ward, B. G. 2005. Case Studies in environmental justice and public transit Title VI reporting. National Center for Transit Research, University of South Florida.

\section{About the Authors}

Ted WANG (Ted.Wang@nyct.com) has been a Staff Analyst since 2007 in the Division of Operations Planning at New York City Transit. He has co-authored published papers on profitability of transit operations and transportation workforce development. His current research interest is in transportation equity and international best practices. He holds an M.A. in Urban Affairs from Queens College, where he focused his interest and thesis on the political feasibility of Bus Rapid Transit for New York City.

ALEX LU (lexcie@gmail.com) is a transit analyst with 14 years of experience in transportation research and railroad management in the United States and Great Britain. Currently an employee of a U.S. commuter railroad, his research interest is in strategic planning, international best practice, and decision-support analyses and algorithms. He obtained an M.S.T. from the Massachusetts Institute of Technology.

AlLA V. RedDY (alreddynyct@gmail.com) is the Senior Director of System Data \& Research in New York City Transit's Division of Operations Planning. He obtained an M.S. in Operations Research from Polytechnic University in Brooklyn in 1976. In his more than 30 years of NYCT experience, he has practiced in the areas of industrial engineering, internal auditing, materials management, performance analysis, and environmental justice. His research interest is in using quantitative research to solve management problems and improve system productivity and efficiency. 